\title{
Popular Bases of the International Labor Movement in the United States and Britain, 1939-1949
}

VICTOR SILVERMAN

Summary: This paper examines the working class in the United States and Britain in order to find a new perspective on the origins and break-up of the World Federation of Trade Unions. While most previous works have focused on the roles of institutions and leaders, this research uncovers the important role played by the thoughts, actions, and inactions of average workers in international affairs. American and British workers, as key constituents of two of the most important organizations making up the WFTU, were not passive observers of world events. Rather, they were critical not only of how the world union movement functioned, but also of the process which came to be termed the Cold War.

In 1940 a British carpenter, L.S. Grindon, offered his fellow trade unionists an analysis of the problems of international order:

From the working-man's point of view, not that anyone bothers about what the working-man thinks, except perhaps his wife, the present situation of international affairs is detached and incomprehensible; it does not belong to him and he wonders why, particularly as patriotism is evidently expected to spring spontaneously from him [ . . ] Prophets of better times, leaders of ideologies, democratic wizards of finance, have each their turn in creating new hopes [ . . ] and soon our beautiful castles of dreams come crumbling down, and history repeats itself leaving the working man out in the cold again."

Grindon expressed the combination of tremendous hope and nagging fear which came to typify the feelings of people around the world in the midforties. The alliance of the USSR and the western powers, the defeat of European fascism and Japanese expansionism, led to an almost universal feeling that this was a great turning point in human history. The optimism affected domestic politics in the great powers and sparked an upsurge in nationalism in the Third World. The idea of the United Nations organization (if not its reality as an instrument of the Big Three) embodied the spirit of this dawning era. Yet Grindon's pessimism also indicated the

1 Amalgamated Society of Woodworkers (ASW), Monthly Journals 81 (March 1940), MSS. 78/ASW/4/120, Modern Records Center, University of Warwick, Coventry (hereafter MRC). 
internal weaknesses of such utopian hopes: they grew out of complex, contradictory thinking about world affairs.

The creation of the World Federation of Trade Unions (WFTU) in 1945 formed an essential part of these optimistic plans for what can be termed the bureaucracy of peace. The World Federation sought to ensure that the unions participated fully in the reordering of the world after the war. It called for a radically democratic system of international relations, one that created a global corporatism. The "UN could not be a success, without the support of the people," British Trades Union Congress (TUC) General Secretary Sir Walter Citrine warned in April 1946, "if [the] WFTU pulled out, [the] UN would collapse."2 Yet within four years of its founding, the WFTU had collapsed, splitting along Communist/antiCommunist lines. A key problem for scholars examining the Federation has been to explain how an organization created with such high hopes could have been so easily shattered.

Almost all works on international labor in the forties see the break-up as stemming from one of two sources. It came about either because of "a headlong clash between [ . . ] rival conceptions of trade unionism", as Anthony Carew puts it, or as a function of government pressure, as Peter Weiler and others would have it. ${ }^{3}$ Both schools base their findings on institutionally oriented research, focusing on government and trade union archives. Because it is usually assumed that such conflict could not be avoided, the sources of conflict and cooperation, beyond the level of power politics, are ignored. Where the actual thinking of the working class is considered at all, it is seen as something simple and unremarkable. I have found to the contrary that popular thought in the US and Britain was quite complex and, moreover, had an important role in creating the WFTU and in affecting the course of the Cold War.

The working classes of the United States, Europe, and the Third World were essential to the failed attempts of the mid-forties to reorganize world politics. Although supportive of the creation of the WFTU, American and British workers held contradictory and quite diverse views about world affairs. These contradictions-especially in the areas of race and national-

${ }^{2}$ Relationship of the World Federation of Trade Unions to the United Nations: Transcript of Meeting of Deputation to the Prime Minister from the Trades Union Congress, April 1, 1946", LAB 13/599-130373, p. 2, Public Record Office, Kew, (hereafter PRO).

"Anthony Carew, "The Schism within the World Federation of Trade Unions", International Review of Social History 29 (1984), p. 335; Denis MacShane, International Labour and the Origins of the Cold War, (Oxford, 1992); Peter Weiler, British Labour and the Cold War, (Stanford, 1988); Horst Lademacher, Jürgen C. Heß, Herman J. Langveld, and Henk Reitsma, "Der Weltgewerkschaftsbund im Spannungsfeld des Ost-West Konflikts", Archiv für Sozialgeschichte 18 (1978): 119-216; Jean-Francois Michel, "La Scission de la Fédération Syndicale Mondiale", Mouvement Social (France) 117 (1981), pp. 33-52; Anthony Carew, Labour Under the Marshall Plan (Manchester, 1987); Vietor Silverman, "Stillbirth of World Order: Trade Union Internationalism from War to Cold War in the United States and Britain, 1939-1949" (unpublished PhD, dissertation, University of California, Berkeley, 1990). 
ism-did not prevent workers from pressing their leaders to support the WFTU at first, but in the latter part of the forties substantially weakened their ability to affect the course of events.

The WFTU grew from the conjunction of three major aspects of the mid-twentieth century. British and American workers' involvement in and reaction to these currents largely determined the role they played in world labor in mid-century. The three aspects were: cooperation with the USSR and Communists throughout the world; the bureaucratization of conflict in international institutions; and the inclusion of Third World people as equals in the process. ${ }^{4}$

In the United States, the leadership of the Congress of Industrial Organizations (CIO) had few reservations about cooperating with the Soviets or other Communists after the German invasion of the USSR in 1941. After all, the organization was based on a popular-front coalition of Communists, Socialists, liberals and bread-and-butter industrial unionists. It seemed logical enough to replicate this alliance world wide. The other American union center, the American Federation of Labor (AFL), was not able to prevent the triumph of the popular front internationalism of the CIO. (The importance of the AFL in the mid-forties has been overestimated because it refused to have anything to do with the USSR. ${ }^{5}$ ) Despite the CIO's consistent internationalism, a tremendous variety of American working class ideas about world affairs limited the commitment of American workers to international corporatism along the lines proposed by the organizers of the WFTU. The contradictory impulses of American working-class political thinking prevented the development of a unified working class voice on global issues. The one way of thinking which unified them, the ideology of Americanism, did not provide a strong basis for the kind of internationalism promoted by the CIO leadership.

In Great Britain, most workers agreed on the shape of the international order they hoped to achieve. Among the great majority of British workers, the USSR occupied a very special position because it appeared to present a model for internal and international transformation. Although they could empathize with people seeking national liberation because British workers

4 Within the WFTU nationalism, how to deal with trade unions in the Third World was the one significant issue before the Marshall plan which caused internal conflict. Ironically, French Communists and British Labourites found common ground in opposing the creation of the WFTU's colonial department and insisted that colonial trade unions could be effectively represented by trade union centers in the imperial homeland. For more on this issue see: interview of Adolph F. Germer by Jack W. Skeels, 11/22/60 Oral History Transcripts, Walter Reuther Archives of Labor and Urban Affairs, Wayne State University, Detroit (hereafter Wayne State); Lademacher et al., "Weltgewerkschaftsbund", pp. 176-178; Weiler, Labour and the Cold War, p. 79.

3 This may come as a surprise to many readers since the bulk of the literature has focused on the AFL and its anti-Communist efforts. Yet in the mid-forties the AFL swam against the political tide. Despite some strong allies it was less powerful than the $\mathrm{ClO}$ for a time. See Silverman, "Stillbirth of a World Order", pp. 274-310. 
had an acute sense of class oppression, they were troubled by the prospect of equality with Third World people. Nevertheless, the idea of including the USSR and the colonial and Third World peoples in a system of worldwide bureaucracy seemed a natural and realistic solution to the world's problems. In all, the relative unity of British workers in terms of their own sense of identity as members of a class, that is, their class consciousness, made them a real force in labor politics. British trade union leaders were on the whole much more distrustful of the USSR and of the prospect of reordering international relations in a radically democratic or corporatist direction. Nevertheless, they found themselves forced into promoting the institutions of the new order. The weak links in British mid-forties internationalism, then, were the anti-communism of the union leadership and the racial awareness of the rank and file.

Understanding the thinking of the working class requires the use of different sources than most scholars have consulted for studying the international labor movement. Complicating the choice of sources, it was often difficult to separate out expressions which came from unrepresentative people, i.e., Communists or other party activists. Particularly helpful were in-depth qualitative surveys which offered an excellent sense of how people thought. ${ }^{6}$ Mass-Observation in Britain, the Survey Research Center, and the Office of War Information in the US were the most notable practitioners of this form of sociological research at the time. Their findings complemented the results of quantitative opinion polls and formed the basis of the findings presented here. I used anecdotal evidence from letters, diaries, newspapers reports and so on where they illustrated these findings.

One of the most remarkable aspects of working-class thought about the issues of internationalism is that it remained largely constant through war and Cold War. Middle-class opinion in both countries was much more volatile, following closely the ups and downs of government and political party positions. ${ }^{7}$ In this respect, trade union leaders were far more similar

- For a discussion of contrasting survey techniques see: A. Strauss and J. Corbin, Basics of Qualitative Research (London, 1990).

'For indications of middle-class ideological flexibility at two key moments in which both Communists and Non-Communists went through ideological nip-flops, see: Office of War Information (OWI), Division of Surveys, "Women and the War", 8/6/42, RG 44, Box 1798 E162, No File; idem, "Special Memorandum No. 85, Attitudes toward International Problems", 8/31/43, RG 44, Box 1803 E164, No File, National Storage Center, National Archives and Records Service, Suitland, Maryland (hereafter NARS-Suitland); Survey Research Center, "Public Attitudes toward Russia and United States-Russian Relations; Part Il: Attitudes and Beliefs about Russia", (unpublished paper, Survey Research Center 4/47), Institute for Social Rescarch (ISR) Report \#220, Institute for Social Research Library, University of Michigan, Ann Arbor, (hereafter ISR Library), p. 32; Office of Public Affairs, Division of Public Studies, Department of State, "Special Report on American Opinion: Opinion of American Labor Organizations on International Questions, January 1, 1948 - March 21, 1948", 3/24/49, RG 59, Box 19 File: "Curr. Attitudes of Am. Labor", Washington National Records Center National Archives and Records Service, Washington, DC (hereafter NARS), 
to the middle class than to the rank and file. They let the party line (whether Communist, Labour, or Democratic) influence their ideas quite strongly. As one study concluded of the rapid endorsement of the Cold War by the middle class in the US, their ideas are "more subject to change as the tenor of world affairs shifts."8 Average workers, in contrast, maintained the same essential ideas through the major political changes of the forties, through the Nazi-Soviet pact period, the Grand Alliance, and the opening years of the Cold War.

The reasons for this constancy are not clear; the evidence does not offer any obvious answers. Some sociologists at the time attributed it to a lack of education and consequent inability to follow events and adjust to changing circumstances. ${ }^{9}$ A more plausible explanation is that middle-class people identified closely with either a state or party. ${ }^{10}$ Workers, in contrast, more alienated from and cynical about the workings of power politics, were less likely to follow a government or party line quickly.

\section{American working-class thought}

Social divisions within the American working class and the split in the American labor movement between the CIO and AFL allowed a minority of politically active workers to exert great influence on the unions" foreign policy. These articulate, involved people, with a variety of left-leaning political perspectives, provided the impetus behind the CIO's actions in the WFTU. Mass sentiment, however, did not move America's workers to unite around a single way of thinking or to feel overwhelmingly positively or, for that matter, negatively toward the Soviet Union or Third World people (with the exception of the Japanese). In contrast to the history of British workers, the story of American working-class thought before the Cold War is a story of what did not happen.

Between the spring of 1939 and the summer of 1941, American workingclass ideas about international issues did not vary greatly. Anti-war sentiment was widespread." Surprisingly, although intellectuals turned

p. 14; Mass-Observation, "Feelings About Russia", Mass Observation Bulletin (23 March 1943), FR 1634, Mass-Observation Archive, University of Sussex, Brighton (hereafter M-O Archive), p. 10; Angus Calder, The People's War: Britain - 1939-1945 (New York, 1969), p. 75; Bill Jones, The Russia Complex: The British Labour Party and the Soviet Union. (Manchester, 1977), pp. 33-54.

"Survey Research Center, "Public Attitudes toward Russia and United States-Russian Relations. Part I: Attitudes Toward United States-Russian Relations" (unpublished paper, Survey Research Center, 3/47), ISR Report \#219, ISR Library, p. ii.

'Ibid., pp. 13, 21.

${ }_{10}$ On this issue see: Noam Chomsky, American Power and the New Mandarins (New York, 1967), pp. 309-320, 323-359; C. Wright Mills, White Collar: The American Mtiddle Classes, (New York, 1951), pp. 324-354.

"Ralph Levering, American Opinion and the Russian Alliance, 1939-1945 (Chapel Hill, 1976), p. 35. 
against it, the USSR weathered the Nazi-Soviet pact with its limited working-class sympathy in the United States intact. ${ }^{12}$ Of course, support for the USSR in the US was much less than in Britain. Reflecting popular hopes of avoiding entanglement in another devastating foreign war, union newspapers ignored international events. The "greatest desire to stay out of the war," poll taker Hadley Cantril reported to the government in the fall of 1940, "is found among the lower income groups [ . . . ] Greatest desire to help England is found among those with above average incomes $[\ldots]^{\prime 13}$

The lack of a dramatic change in working-class ideas after the Nazi invasion of the USSR in 1941 further reveals the consistency of workingclass opinion. From the summer of 1941, the middle class tended to be more sympathetic, though workers gradually became increasingly positive about the Russians. ${ }^{14}$ At a large shipyard in California, for instance, female workers refused to let visiting Russian stewards use their bathroom. "Almost everybody," said a guard at the dock, "just don't trust the Russians." 15 Distrust of the Soviets was one expression of a general cynicism about propaganda that pervaded the working class. "All them politicians is as crooked as a cowpath, anyhow", another shipyard worker observed. ${ }^{16}$

With the shift in the fortunes of the war in 1943 and the first successful conferences of Big Three, people began to focus more clearly on post-war plans. Those who expressed ideas most similar to those of British workers tended to have a strong sense of class identity. O.G. Overcash, a United Automobile Workers (UAW) activist in Muncie, Indiana, for instance, believed deeply in international solidarity based on working-class comradeship. "When the workers of the world work and play together, no Dictator can rule them long", he wrote in $1943 .{ }^{17}$ Men and women like

12 Harvey Klehr, The Heyday of American Communism: The Depression Decade (New York, 1984), pp. 386-400, 407; Irving Howe and Lewis Coser, The American Communist Party: A Critical History, (New York, 1962), pp. 273-387; Earl Browder, "The American Communist Party in the Thirties", in Rita James Simon, ed., As We Saw the Thirties: Essays on Social and Political Movements of a Decade (Urbana, IL, 1967), p. 244.

"Hadley Cantril, "America Faces the War: The Reaction of Public Opinion"', 12/16/40, RG 44, Box 1796 File: [none], NARS-Suitland, p. 10.

14 OWI, Division of Surveys, "Women and the War", 8/6/42, RG 44, Box 1798 E162, No File, NARS-Suitland, tables 14a-b, 16a-b; idem., "America Views the Post War World; Division of Surveys Report Number 14", 5/28/42, RG 44; Box 1784A; File: "America Views the Post-War World," table 14, OWI, NARS-Suitland; idem., "Special Memorandum No. 85, Attitudes toward International Problems," 8/31/43, RG 44, Box 1803 E164, No File, NARS-Suitland, p. 9. See also: Melvin Small, "How We Learned to Love the Russians: American Media and the Soviet Union during World War II", Historian 36 (May 1974), pp. 455-478.

1s Katherine Archibald, Wartime Shipyard: A Study in Social Disunity (Berkeley, 1947), p. 208.

16 Ibid., p. 200.

17 O.G. Overcash to James Carey, 6/13/43, ACC. 185, Box 132 File "Report on Labor Conditions in Bolivia, 1943", CIO Secretary Treasurers Collection (hereafter CIOST), 
Overcash whose lives revolved around the labor movement found international solidarity a compelling ideal.

The best hope for the future, according to internationalistically minded workers, was a just political and economic order. A southern carpenter explained: "It's one world now and we got to go in and do our share. The Union's taught me that. Workers everywhere want it fair for all."18 The alternative to war and depression was some sort of international organization, a system which recognized the needs of working people. Many stressed that the United States' role should not be to dominate the future international order. ${ }^{19}$

Yet such internationally minded workers were in a minority in the midforties. There were few elements of consensus among American workers. Many lacked a strong commitment to the ideals of the war whether of national interest or of internationalism such as those articulated in the Atlantic Charter. Strikes and other forms of industrial conflict continued, apathy was widespread. Workers responded cynically to appeals for greater efforts at work or sacrifices at home. ${ }^{20}$ Relatively few workers thought actively about post-war plans or methods of avoiding future conflicts. "There are a few of us who are really concerned with the post-war world", wrote Private Irving Salert, a former United Electrical Workers Union (UE) activist in 1944, "No one speaks much about it."21

Far more common than left-wing internationalists, nationalistic Americans from all classes believed the United States would have to take a stronger role in the world. One California steelworker, for instance, believed the failings of foreigners necessitated the US assuming the mantle of world power:

I want a United States Army, Navy and Air Force that can whip the world anytime they turn around. We will have to police the world [ . . . The Europeans are a bunch of sheep. They are not equal to our kind. We will have to take a front scat in international affairs. ${ }^{22}$

Even more in need of guidance than Europeans, according to many Americans, were people from the colonial world. In the area of relations with the Third World most workers, with the telling exception of African Americans, supported a two-sided US policy. On the one hand, they opposed the creation of an American empire after the war. On the other,

\footnotetext{
Walter Reuther Archives of Labor and Urban Affairs, Wayne State University, Detroit (hereafter Wayne State).

1s OWI, Division of Surveys, "Report Number 25: Conceptions of the Role of America in World Affairs: Part I", 9/29/42, RG 44, Box 1786, No File, NARS-Suitland, p. i.

19 Paul Cressey, Intensive Interview \# 4-T19, [nd, 12/2/42], RG 44, Box 1823 E168, File: "Paul Cressey Field Reports", NARS-Suitland, p. 4.

" For a survey of wartime conflicts see: Nelson Lichtenstein, Labor's War at Home: The ClO in World War II (Cambridge, 1982).

"Irving Salert to James Carey, [nd, 5/44], Acc. 185, Box 3 File: "Correspondence, Salert, Irving", CIOST, Wayne State.

"OWI, "The Role of America in World Affairs: Part I", p. iii.
} 
they expected the United States to play a dominant role in world affairs, ensuring that the future would not bring renewed war, privation, or challenges to American hegemony. "We might be asked to protect small countries," a mechanic in a rubber factory explained, "but we have no interest in dominating them."123

The long history of American racial attitudes and of racial conflict in the United States prefigured attitudes toward the rise of the Third World and the end of colonialism. Hatred of the Japanese during the war, for instance, revealed the underside of American attitudes toward foreigners. Katherine Archibald noticed the contrasting perceptions of Japanese and Germans among her fellow workers:

Anger against the Germans was mainly channeled [ . . ] toward the single leader or the single group deemed to have misguided a worthy folk, but anger against the Japanese was directed against a nation and a people, and with the publicizing of every new Japanese atrocity the bloodthirsty shouted for the annihilation of the foe down to the veriest babe. ${ }^{24}$

Even among the radical west-coast longshoremen, anti-Japanese feeling led to ugly incidents after the end of the war. ${ }^{25}$ Hatred of the Japanese revealed a society-wide fear and aggressiveness toward the Third World.

Although intellectual identification with colonial liberation movements was common, few would support an active anti-colonialism. However, African-Americans, unlike the majority of American workers, identified strongly with colonial peoples. They criticized Britain's imperial role and attributed the country's problems in the world to racist thinking. A Detroit laborer's analysis of British imperialism reflected a sense of his own oppression in the United States:

England always treated the colored people bad. India's been a slave for years, and now they just want to be free so they can fight the Japs [ . . . ] If I were an Indian, I'd say to England kill us, kill everybody, let the Japs come in, let the whole world go to hell, but I want my freedom now. I don't want any promises $[\ldots]^{\prime 26}$

The contrast between black and white attitudes on colonial issues points to the great range of thinking among workers, variations growing from an enormous diversity of backgrounds, experiences, and expectations. There were few issues which united American workers between or within ethnic groups.

The divisions within the working class carried over into the early postwar period. There was little unity either for or against the emerging tenets

23 OWI, "America Views the Post War World", p. 3.

24 Archibald, Wartime Shipyard, p. 191.

25 Harvey Schwartz, "A Union Combats Racism: The ILWU's Japanese-American "Stockton Incident" of 1945", Southern California Quarterly 62 (Summer 1980). pp. 161-176; John Dower, War Without Mercy: Race and Power in the Pacific War (New York, 1986), pp. 315, 33-73.

${ }^{25}$ OWI, Division of Surveys, "Anti-British Attitudes of Negroes", 10/3/42, RG 44; Box 1784; File: "Survey"s Special Reports \# 24". NARS-Suitland, p. 4. 
of the Cold War - even among groups usually considered wholly antiCommunist. It is often assumed that Catholic workers, influenced by the teaching of the Church and the activism of anti-Communist priests, uniformly disliked and distrusted the left. ${ }^{27}$ Reality, however, was more complex. The strength of groups like the anti-Communist Association of Catholic Trade Unionists (ACTU) led people to believe that American Catholics espoused uniform ideas. However, many Catholic communities divided painfully over Communism. ${ }^{23}$

More important than religious identification in influencing thoughts on international affairs during the mid-forties was national background, although support for the Communists, for tolerance of the Soviet Union, and for a new world order could be found in varying degrees in most ethnic groups. A survey of UAW convention delegates in 1946 and 1948 found greater support for the Communist-Centrist alliance in the UAW among those with Eastern European, Italian, and Greek names. The anti-Communist group tended to draw its strength from those with British, French, German, and Dutch names. ${ }^{29}$ Irish-Americans dominated the anti-Communist ACTU. ${ }^{30}$ Eastern European Jews, Southern Slavs, and Finns disproportionately, though not overwhelmingly, supported Socialist and Communist causes. ${ }^{31}$ Black workers were another source of left support in the union movement. Appalachians tended to support the right. ${ }^{32}$

Naturally, no ethnic or racial group was entirely Communist or Socialist, left or right despite these proclivities. ${ }^{33}$ Even Eastern European communities, a critical constituency supporting anti-Soviet policies immediately following the war, suffered from deep ideological differences. The Poles, for instance, had a strong pro-Communist faction..$^{34}$ Factionalism could even set brother against brother as in the case of the UE's largest local,

27 Revisions of these ideas can be found in Ronald Schatz, "American Labor and the Catholic Church, 1919-1950", International Labor and Working Class History (Fall 1981), pp. 46-53; Steve Rosswurm, "The Catholic Church and the Left-Led Unions", in Steve Rosswurm, ed., The ClO's Left-Led Unions (New Brunswick, NJ, 1992).

as David J. O'Brien found substantial divisions and resistance to political leadership by the Church. O'Brien, America Catholics and Social Reform: The New Deal Years (New York, 1968), pp. 89,248 n.

29 Martin Halpern, UAW Politics in the Cold War Era (Albany, NY, 1988), pp. 129-130.

${ }^{30}$ Douglass Seaton, Catholics and Radicals (Lewisburg, PA, 1981), pp. 57-58.

31 Nathan Glazier, Social Bases of American Communism (New York, 1961), pp. 42, 130133.

${ }^{32}$ Peter Friedlander, Emergence of A UAW Local, 1936-1939: A Study' in Class and Culture (Pittsburgh, 1975), p. 125.

${ }^{33}$ See James N. Gregory, American Exodus: The Dustbowl Migration and Okie Culture in California (Ncw York, 1989), pp. 150-171; Glazier, Social Basis of American Communism, pp. 130-131.

is Two good works on the internal history of Polish-American communities are: Margaret Nowak, Two Who Were There: A Biography of Stanley Nowak (Detroit, 1989); John Bukowczyk, "And My Children Did Not Know Me": A History of the Polish Americans, (Bloomington, IN, 1987). 
Pittsburgh's 601, where Mike and Tom FitzPatrick battled for the leadership of the local at the head of popular front and anti-Communist factions. ${ }^{35}$ At the dawn of the Cold War, American workers were deeply divided in their attitudes toward the USSR and about Communist/anti-Communist issues in general.

Predictably, mobilization for the Cold War did not evoke an immediate response among the American people. A survey in April 1947, shortly after President Truman's call for aid to Greece and Turkey, found the public unsure and unenthusiastic about the new direction of US foreign policy: more people disapproved of sending military supplies to Greece than approved..$^{36}$ In its initial stages, the United States' position in the Cold War was not a popular stance.

Although Americans were not as inclined to take the Soviet side in conflicts as British workers were, they nonetheless could not bring themselves immediately to abandon the hopes of the mid-forties. Class distinctions affected foreign policy thinking. Those people who most closely followed the government's rapidly fiuctuating line tended to be more highly educated or wealthier than average. ${ }^{37}$ In 1948,19 percentage points more college-educated people than elementary school-educated thought the Soviets were trying to "get control of [ . . ] ] other European countries." 38 One Roper poll found only a third of factory workers in favor of the Marshall Plan in early $1948 .{ }^{39}$ Such feelings did not necessarily mean opposition. Willard Townsend, CIO Vice President and head of the largely African-American Transport Service Employees, reassured a Department of State official in 1947 that "the ordinary member [of my union] is largely concerned with working conditions, wages, etc., and is not deeply interested in international developments". ${ }^{40}$

The tremendous divisions in the United States between and within ethnic and racial communities prevented the emergence of a unified working-class voice in international affairs in the 1940 s. The great divide

3s Seaton, Catholics and Radicals, p. 226; Ronald Schatz, The Electrical Workers: A History of Labor at General Electric and Westinghouse, 1923-1960 (Urbana, IL, 1983), pp. 198-199. 36 Survey Research Center, "Public Attitudes toward American Foreign Policy; Part I: Patterns of Attitudes toward American Foreign Policy" (unpublished paper, Survey Research Center, 5/47), ISR Report \#222, ISR Library, p. iii.

${ }^{37}$ Survey Research Center, "Public Attitudes toward Russia and United States-Russian Relations; Part I", p. ii, 13, 21.

34 89 percent of college-educated though this as opposed to 70 percent of the elementaryeducated. Survey Research Center, "Public Attitudes toward Russia and United States Russian Relations; Part II: Attitudes and Beliefs about Russia" (unpublished paper, Survey Research Center 4/47), ISR Report \#220 ISR, p. 32.

${ }^{9}$ Office of Public Affairs, Division of Public Studies, Department of State, "Special Report on American Opinion: Opinion of American Labor Organizations on International Questions, January 1, 1948-March 21,1948", 3/24/49, RG 59 Box 19 File: "Curr. Attitudes of Am. Labor", NARS, p. 14.

* Memorandum of conversation, 2/11/47, RG 59; 841.594-IVFTU/2-1147, NARS. 
between the CIO and the AFL not only represented conflicts of union styles and programs, but in a way also reflected the fragmented nature of the American working class. Some elements of trade union universalism and economic fears encouraged unity, but it was the ideology of Americanism which provided the most powerful and unifying awareness for the diverse American working class. ${ }^{41}$

Insecure in the nature of their Americanness, members of minority groups, Jews, Slavs, Poles, French Canadians, African Americans, Finns and so on, all sought to fit in to majority society. The major cultural achievement of the CIO and the New Deal was a politics of cultural pluralism, which provided minority Americans with a legitimate avenue to American self-consciousness. During the mid-forties the ideas of cultural pluralism inherent in New-Deal Americanism easily transferred to the multiple nations of the world and justified acceptance of a major Soviet role in world affairs. Just as people of all ethnic backgrounds and value systems could become Americans in a culturally plural system, so could all nations of any political system (except for aggressive fascism) participate in the United Nations.

As the left lost power in the late forties and early fifties, however, the idea of Americanism became more associated with the right and with loyalty to the western cause in the Cold War. The idea that UnAmerican Activities were those which supported a New-Deal foreign policy threatened the achievements of the Americanized groups which made up the New-Deal coalition. Although labor attempted to use Americanist imagery and patriotic thinking to resist the shift in American politics, it did not succeed.

Ethnic Americans were thus faced with the following challenge: abandon what remains of their left-internationalistic thinking, abandon the hope of increasing labor power in the society, and demonstrate loyalty to the foreign policy of the United States, or lose their claim to Americanness. Combined with the apparently unjustified aggressiveness of Soviet foreign policy, the changing conception of Americanism substantially reduced the popular base for mid-forties internationalism in the US labor movement. By the end of the decade, the pro-Soviet left was a small

\footnotetext{
1 There is substantial dispute about whether or not the cultural and political unity created by the labor version of Americanism and the working class version of mass culture empowered the working class. See: Nelson Lichtenstein, "The Making of the Postwar Working Class: Cultural Pluralism and Social Structure in World War II". Historian 51 (November 1988): 42-63; Lizabeth Cohen, Making A New Deal: Industrial Workers in Chicago, 1919-1939 (New York, 1990); Thomas Gobel, "Becoming American: Ethnic Workers and the Rise of the CIO", Labor History 29 (Spring 1988), pp. 173-198; Gary Gerstle, Working-Class Americanism (Cambridge, 1989); Christopher Lasch, The Agony of the American Left (New York, 1969); Warren Susman, Culture as History: The Transformation of American Society in the 20th Century (New York, 1984); Mike Davis Prisoners of the American Dream: Politics and Economy in the History of the US IVorking Class (London, 1986).
} 
minority. Despite the lack of a coherent position on world issues and the diversity of working-class groups, a common pattern of thought emerged by the end of the 1940s. This pattern, based not in class conceptions but in an ideology of Americanism, did not sustain the CIO's international policy.

\section{British working-class thought}

In contrast to the Americans, British workers had a decidedly class-based world view. Benefiting from an imperial economy, native British workers considered themselves superior to foreigners, colonials, and immigrants. Yet they also experienced real class oppression and hardship especially as Britain's dominance of the world economy declined. Further, the terrible price in human lives exacted by the United Kingdom's involvement in Europe's wars impressed on Britons the importance of reorienting the way nations interacted. They perceived the post-war world in class terms, believing the USSR was a pro-working class force in global politics. Yet as their position as a subordinate class within a weakening, but still formidable world power suggests, working people experienced deeply contradictory impulses. The potentials of the wartime alliance allowed a synthesis of these impulses and made pursuit of a new world order plausible. The crises of the Cold War, however, exposed the hidden fault lines of universalist thinking-nationalism, racism, and self-interest-which eventually shattered the wartime dreams of world order.

The breakdown in world order in the 1930s confirmed the belief that international relations needed to be reordered to avoid future wars. The UK, as an imperial power and one of the USSR's chief pre-war antagonists, had to accept radically different techniques and goals in its foreign policy. This meant in practice bureaucratizing and containing conflict and was a confirmation of traditional Socialist internationalism. This is not to argue that British workers were not patriotic, but rather that the British Socialists opposed the aggressive nation state.

Working people adhered to the Labour party in part because they saw it as an alternative to the violent nationalism common among Conservatives which they believed was a source of war. Likewise, Labour's internationalistic impulse dissuaded nationalistic workers from joining Labour, even if they might share other concerns with it. G. A. W. Tomlinson, a Nottinghamshire coal miner, and son of a life-long Socialist, recalled that his conversion to Conservatism began at a Labour meeting at the local movie theater when the speaker dismissed patriotism:

[The speaker] said (and I shall never forget the effect of his words on me): "What is this England that you are supposed to love? It is only a tiny portion of the earth's surface. Why should you be expected to love it, or be prepared to die for it any more than you would for Russia, China, or Greenland?" 
I was thunderstruck. "Because it is England!" I yelled out in fury [ . . ] Didn't they know that most of the happiness that ever I had came from this love of England that they spoke so contemptuously about? [ . . . The socialists, I decided were a lot of mugs. I didn't want anything to do with them and I went home and told my father so. ${ }^{42}$

Only a minority agreed with Tomlinson. They tried to balance their sympathy for the Soviet Union, their resentment of their own nation's class structure, and their feelings of patriotism. ${ }^{43}$

The Nazi-Soviet Pact and the Finnish-Soviet war upset many believers in the Soviet Union's positive world role, but still did not eliminate basic sympathy with the USSR. Mass-Observation consistently found that working people would not believe the USSR was in the wrong, or might even become an enemy of Britain. Even at this low moment of Soviet popularity, the majority shared the optimism of one man who affirmed in 1939: "You never know with Russia; she's a dark horse. I still believe she'll come in on our side."

Once the Nazis turned on the USSR in 1941, working people perceived a connection between the Soviet system and that nation's ability to resist the Nazi onslaught. One worker told Mass-Observation: "During the last war they were under a monarchy with precious little to fight for. This time things are different. They are fighting for their country; the Russia they've created themselves." 45

The alliance period proved a heady time for internationally minded working people because, in addition to finally providing a powerful ally on the Continent, it appeared to solve the biggest problem of their nation's foreign policy: its ideological opposition to the USSR. In the summer of 1941 as German armies pushed into the Soviet Union, a railwayman expressed his feelings about his country's new alliance:

When that [victory] day arrives, beside the Union Jack - saved from coronation day - that [which] will hang out of my bedroom window will be the Red Flag. If

12 G. A. W. Tomlinson, Coal-Mfiner (London, n.d. [1937]), pp. 92 ff.

43 The most recent work on British working-class patriotism underplays the importance of international issues though it does comprehend the ability of the working class to develop its own synthesis of patriotic and socialist ideas. Geoffrey Field. "Social Patriotism and the British Working Class: Appearance and Disappearance of a Tradition", International Labor and Working Class History 42 (Fall 1992), pp. 20-39; Raphael Samuel, ed., Patriotism: The Mfaking and Unmaking of British Identity, 3 vols. (London, 1989); Alan J. Lee, "Conservatism, Traditionalism and the British Working Class", in David E. Martin and David Rubinstein eds., Ideology and the Labour Movement (London, 1979); Hugh Cunningham, "The Conservative Party and Patriotism" in Robert Colls and Philip Dodd, eds., Englishness: Politics and Culture, 1880-1920 (London, 1986), pp. 283-307.

" Mass-Observation, "Feelings About Russia", Mass-Observation Bulletin, 23 March 1943, FR 1634, M-O Archive, p. 10.

45 J.H., "Feelings about Russia", 20 November 1942, FR 1492, M-O Archive. (In MassObservation file reports (FR) and topic collections (TC), the authors and interviewers are often only cited by initials.) 
the latter can not be had for love or money, then I will borrow one from a signal cabin and get the wife to sew the jolly old hammer and sickle on it. Before the Soviets signed the non-aggression pact I was inclined to communism. To-day I declare myself a Communist, with the exception, love of King and country. Long live the King, Churchill, Stalin, and Roosevelt! ${ }^{\text {th }}$

The railwayman's statement joins together the diverse elements that epitomized working-class thought in the mid-forties and which the Cold War was to later shatter. He was able to combine a sense of British nationalism with support of the USSR.

Support for Russia had its most concrete effect in the workplace. By the fall of 1941 normal propaganda efforts to increase production appeared to be faltering, ${ }^{47}$ but workers increased the output of armament plants by 20 percent during the last week of September 1941, when the government pledged that the entire week's production would be shipped to Russia. ${ }^{48}$

Nothing expressed better the feelings of working people toward the USSR than the reception given to touring delegations of Soviet trade unionists. During the war, the Soviets visited dozens of factories and mines, almost uniformly receiving a warm greeting. Union official A. R. Rollin joined a group in a Castleford mine:

The atmosphere was warm, the miners were only dressed in shorts and their bodies covered with coal dust. But they cheered wildly in acknowledgement of the greeting from their Russian comrades conveyed to them by the delegation and the latter's appeal for increased production to defeat the common enemy [ . . ] The foreman who guided us said that the delegation's visit was the best thing that had happened since the war and that it was the first time in his forty years experience that he heard cheering miners down in the pit. ${ }^{49}$

The persistence of support for the Soviet Union into the late forties is one of the unexplored factors in the development of the Cold War. Envy and admiration of the Soviet system was not turned easily into endorsement of Anglo-American foreign policy. Most British working people, and a good many from the middle and upper classes as well, believed that the Soviet Union had a legitimate interest in influencing the reconstruction of the continent.

4 Railway Review, 5 September 1941.

47 On this issue see: Harold L. Smith, ed., War and Social Change (Manchester, 1983); Henry Pelling, Britain and the Second World War (London, 1970); Angus Calder, The Myth of the Blizz (London: 1991).

48 Ministry of Information (MOI), "Home Intelligence Weekly Reports, \#50", 17 September 1941: Ministry of Information, "Home Intelligence Weekly Reports, \#52", 1 October 1941, INFI/292, PRO.

49 [A. R. Rollin], "With the Soviet Trade Union Delegation: Description of Visit" [nd, 1942], A. R. Rollin Papers, MSS.240/T/3/22, MRC. 
This belief in Soviet legitimacy led many workers to support the USSR in its conflict with the Poles, in contrast to the policy of their own government. Prejudice against Polish exiles and immigrants in Great Britain increased distrust of Polish nationalism and re-enforced a willingness to the think the best of the USSR's intentions and policies. In this case xenophobia supported internationalism. ${ }^{50}$ The parallels between the experiences of the Poles in Britain and those of immigrants from the Third World are striking. While the main reaction to both groups was intolerance, in many cases Britons behaved quite decently. The difference is that in the case of the Poles, intolerance ended up supporting left-wing internationalism, while in the case of people of color it undercut it.

Hundreds of thousands of Poles spent the war in England, many staying on after the war. British reaction to these immigrants was largely intolerant, based on a combination of xenophobia, anti-Catholicism, economic competition, and pro-Sovietism. ${ }^{31}$ Inter-group conflicts abounded. It was practically impossible to employ mixed groups of Polish and British workers. Instead, employers had Poles work in single nationality groups within mixed factories or job-sites - a technique also used with the Irish and racial minorities. ${ }^{52}$ Internationalism, the Poles learned, did not mean tolerance, and it apparently only applied to people far away. "For in no country," one Pole sadly explained, "is the word foreign so offensively pronounced." $" 33$

Feelings about the Poles in Britains translated into dislike of Poles abroad. Workers in Scotland and the North Midlands (where most of the Poles were), the Ministry of Information reported in 1943, "accept the Russian point of view" about the breaking of relations with the Polish government. ${ }^{54}$ Only 3 percent blamed the Soviets for the break, while 56 percent blamed the Poles. ${ }^{55}$ Underscoring their trust in the Soviets, many did not believe that Soviets had massacred Polish soldiers in the Katyn Forest. ${ }^{36}$

Like attitudes toward Continentals, working-class thought about Third World peoples revealed a mix of ideas based on prejudice, experience, and self-interest, demonstrating the ambiguity of internationalism. It is difficult to find information on working-class attitudes toward Third World and colonial politics in the 1940s, but the way the British thought about the

so The following sections is based on Jerzy Zubrzycki, Polish Immigrants in Britain (The Hague, 1956), which remains the standard work on the Polish presence in the UK. Sec also J.A. Tannahil, European Volunteer Workers in Britain (Manchester, 1958).

s1 MOI, "Home Intelligence Weekly Reports: No. 164", 25 November 1943, INF1/292. PRO.

32 Zubrzycki, Polish Immigrants, p. 170; Tannahil, Volunteer Workers, pp. 57-65.

${ }^{3}$ Zubrzycki, Polish Immigrants, p. 208.

34 MOI, "Home Intelligence Weekly Reports, \# 134", 24 April 1943, INF1/292, PRO.

ss Mass-Observation, Mass-Obsenvation Bulletin, 10 May 1943, FR 1676, M-O Archive, p.16. ss Ibid. 
minorities in their own midst - for which there is more data - undoubtedly influenced their expectations for those abroad. ${ }^{57}$ The small numbers of people of color in the 1940 s, approximately 100,000 , allowed race relations to take on quite varied patterns. ${ }^{58}$ Early immigrants did not uniformly have hostile or isolating experiences. ${ }^{39}$

Most black immigrants were sailors and lived in port town ghettos, but hundreds also labored in factories during the war. In a number of plants in the Midlands, natives refused to work side by side with immigrants. Trade unions also put up resistance to their employment by refusing entrance to journey-level workers. ${ }^{60}$ In areas with larger foreign and immigrant populations, most notably seaports such as Glasgow, Liverpool and Cardiff, race relations during the war also maintained their familiar form. ${ }^{61}$ Even after the war, the Glasgow National Union of Seamen, one of the few Communist/left branches in the union, reaffirmed its opposition to the hiring of Indians or Arabs - even if they were British citizens. ${ }^{62}$

Traditional English and Scottish intolerance of the Irish and Jews continued through the war. ${ }^{63} \mathrm{~A}$ Midlands factory manager explained that he had the same difficulties with Anglo-Irish integration in his plant as he did with black-white relations. ${ }^{6+}$ Indeed, long-held English attitudes towards the Irish probably provided the pattern for the way they related to people of color. ${ }^{65}$ Anti-Semitism, too, remained a serious social problem, espe-

I7 Ken Lunn, "Race Relations or Industrial Relations? Race and Labour in Britain, 18801950", Immigrants and Minorities 4 (July 1985), p. 10; The best surveys are Laura Tabili, "Black Workers in Imperial Britain" (unpublished PhD dissertation, Rutgers University, 1985); J.L. Watson, ed., Between Two Cultures: Migrants and Minorities in Britain, (Oxford University Press, 1977); C. Holmes, John Bull's Island: Immigration and British Society (London, 1988);

ss Leonard Bloom, Introduction to Negroes in Brisain by Kenneth Little (London, 1948, 2nd revised edition, 1972), p. 4.

99 Examples can be found in: Michael Banton, The Coloured Quarter: Negro Immigrants in an English City (London, 1955), p. 189; MOI, "Home Intelligence Special Report: No. 34, Hondurasian [sic] Lumbermen in Scotland", 3 December 1942, INF1/293, PRO.

${ }^{\infty}$ Marika Sherwood, Many Struggles: West Indian Workers and Service Personnel in Britain, 1939-1945 (London, 1984), p. 74.

${ }^{61}$ For instance see: MOI, "Home Intelligence Weekly Report: No. 41. Special Report on the Merscyside and Clydeside", 16 July 1941, INFI/292, PRO. The ports had a checkered history. See for instance, Roy May and Robin Cohen, "The Interaction of Race and Colonialism: A Case Study of the Liverpool Race Riots of 1919", Race and Class 16 (October 1974), pp. 111-126; and Neil Evans, "The South Wales Race Riots of 1919", Llafur 3 (1983), pp. 76-87.

62 National Union of Seamen, Executive Council Minutes, 24 October 1947, MSS. 175/1/1/10, MRC.

w Richard Croucher, Engineers at War (London, 1982), p. 201. For examples of reactions: WAL, Extracts From Diary 10/9/41 - 26/1/41, 10 September 1941, TC75/7/A, M-O Archive. * Banton, Coloured Quarter, p. 145. Banton, Coloured Quarter, p. 145.

as Little Negroes in Britain, p. 190; Winthrop Jordan, White Over Black (New York, 1977), pp. 87-88. 
cially after the Blitz when large numbers of Jews left their London ghettoes. ${ }^{66}$

This emerging pattern seemed to fit the people of Britain's overseas empire. As several other scholars have pointed out, working-class and Labour commitment to Indian independence was shot through with paternalism and racist assumptions. ${ }^{67}$ Many in the Labour leadership shared the view of Foreign Minister and former Transport Workers Union leader Ernest Bevin view of the Empire as "essential to our survival as a great power". ${ }^{68}$ In its early months the Labour government pushed for control over former Italian possessions in Africa and for other additions to the nation's holdings. ${ }^{69}$ Nonetheless, the idea of empire had always been troublesome for Labour and became increasingly difficult for Labourites in and out of the unions to maintain. ${ }^{70}$

The principles of equality and self-determination appealed to many people, but such ideals faded when confronted with what the loss of great power status meant, or with what the self assertion of Third-World nationalists implied for British notions of superiority. A group of soldiers interviewed during the war expressed this succinctly. The soldiers claimed they favored racial equality. Yet when asked if that meant they would follow a black officer, one soldier replied that it would be unlikely since they had "refused to obey even a white French officer."

A combination of ignorance, underlying bias, and trust in the good intentions of leadership in regard to the Third World encouraged working people to give those in authority a wide latitude for pursuing foreign policy. The bitter conflicts within the unions, and between the unions and the government over wages policy and nationalization, should not obscure the willingness of workers to follow their leaders on issues where they had growing

*6 Tony Kushner, The Persistence of Prejudice: Antisemitism in British Society during the Second IVorld IVar (Manchester, 1989).

67 See, for instance: P. Gupta, Imperialism and the British Labour Movement (London, 1972); R. J. Moore, The Crisis of Indian Unity (Oxford, 1974); J. A. Gallagher, The Decline, Revival and Fall of the British Empire (Cambridge, 1982).

" Quoted in Kenneth O. Morgan, Labour in Power, 1945-1951 (Oxford, 1984, paper ed. 1985), p. 193. Bevin's attitude toward the British Empire is more positively portrayed in Alan Bullock, Ernest Bevin: Foreign Secretary (London, 1983), pp. 30-36. However, even Bullock admits that Labour believed that maintaining Britain as a world power required some form of imperial reach.

69 Morgan, Labour in Power, pp. 190-192.

${ }^{70}$ Left and right unions endorsed immediate Indian independence in 1944-1945. NUR, "Procecdings and Reports for the Year 1944", February Special Executive Meeting , MSS. 127/NU/1/1/35, MRC; ASW, Monthly Journals 83 (September 1942) MSS. 78/ASW/4/22, MRC, p. 375; idem, Monthly Journals, December 1944, MSS. 78/ASW/4/23, MRC; Idem. Mfonthly Journals 86 (March 1945) p. 104; TGWU, "Minutes and Record of the Proceedings of the Eleventh Biennial Delegate Conference" (London, [n.d., 1947]), MSS. 126/ \& G/1/4/11, MRC.

$"$ Little, Negroes in Britain, p. 255. 
doubts. Few voiced opposition as their country came into conflict with the USSR and the Communists abroad. Although by the fall of 1947, the largest group of working-class respondents expressed unfavorable opinions of the USSR, an anti-Soviet majority did not emerge at this time. Their replies to surveys, as social scientists Tom Harrison and H.D. Willcock put it, "take on a plaintive rather than positively hostile note" $[\ldots]^{72}$

Many working people felt anxious, worried and disappointed about international affairs after 1945. Disenchantment with this world led to contemplation of others. Tom Harrison discovered in 1947 a rise in belief in astrology and UFOs. Seeing the disorder of international politics transferred to the natural world, many also believed that atomic weapons had caused the severe winter of 1946-1947. Harrison found, as have scholars examining the culture of the 1950s, greater participation in sports, gambling, and drinking. ${ }^{73}$ The level of overall interest in international affairs declined rapidly after the war. Communist repression in Eastern Europe undoubtedly weakened the appeal of world cooperation and increased support for the TUC's attempt to revive the restrictions on Communists developed in the twenties and thirties. Even so, anti-Communism failed to develop a mass working-class base or inspire tremendous passion among trade unionists or the working class at large.

Britons were willing to believe that they had a special role in the world, that they could influence the course of events in Europe and Third World countries. Yet the underlying distrust of people of color and foreigners in general and the growing minority opposed to the USSR's actions in Eastern Europe weakened the commitment to internationalism. When the working-class leadership switched its line after the break-down of the alliance and the confrontations of 1946-1947, British workers, except for a minority of Communists and other radicals, were unwilling to oppose their leaders on foreign policy. During the 1940s, the combination of forces and ideas which encouraged thinking about a new international order and the social transformation of Britain itself proved inherently unstable. The reversal in working-class thinking about world affairs turned out to be a painful and drawn-out process. The British people did support the Cold War, but unwillingly, with many exceptions, and certainly without the messianic enthusiasm for anti-communism which gripped the United States. Instead, the dreams of the mid-forties evaporated in a wave of cynicism and disappointment. The change is perhaps best summed up in a Labour Party meeting in a small town:

$n$ Tom Harrison [and H.D. Willcock], "British Opinion Moves toward a New Synthesis", Public Opinion Quarterly 11 (Fall 1947): 330.

"rlbid., p. 339; On mass culture see: Nick Tiratsoo, "Popular Politics, Affluence and the Labour Party in the 1950s', in A. Gorst ef al., eds., Contemporary British History, 19311961 (London, 1991); Frank Bechofer, J. Goldihorpe, D. Lockwood, and Jennifer Platt, The Affuent Worker: Political Attitudes and Behavior (London, 1968); and idem, The Affluent Worker in the Class Structure (Cambridge, 1969). 
"I've a letter here about British Guiana," the secretary said, "it's a bit of a long letter. Does anyone want me to read it?"

"Don't bother," one of the ladies cried out, "we've enough trouble in Ashton." The letter was accordingly left unread. ${ }^{74}$

Sir Walter Citrine had unwillingly embraced the Soviets during the war in order to prevent Communists and their allies in the TUC from taking advantage of an overwhelmingly pro-Soviet internationalism among the rank and file. ${ }^{75}$ His successors, Arthur Deakin and Vincent Tewson, were able to engineer the TUC's withdrawal from the WFTU in 1949 without significant opposition.

\section{The fate of labor internationalism}

In both the United States and Great Britain, the Cold War lacked immediate appeal among the working class. Support for the international labor movement, however, could not withstand the domestic political pressures of the Cold War. In the United States, worker apathy and a patriotic ideology undercut the left-leaning union leadership's initial efforts on behalf of world labor after the war. The growing pressure of domestic anti-Communism forced the CIO leaders to abandon their popular front thinking and practices. In Great Britain, the anti-Communist leadership counteracted weakening rank-and-file leftist impulses which threatened to provide a basis for Communist power in the unions. The weakness of the mid-forties version of labor internationalism in both cases resulted from the nature of working-class thinking which was in turn based in essential aspects of people's experiences. The realities of tremendous American cultural diversity in a context of growing world power were the essential influences on working-class thought. Class unity in Britain was contrasted with a fear for British greatness, an increase in disillusionment with the USSR, and a growing cynicism coupled with a belief in the beneficent intentions of the Labour leadership-at least in the area of foreign relations. The net result for both the US and the UK was fundamental weaknesses in the working-class support which underlay internationalism.

As L.S. Grindon had predicted, the "castles of dreams came crumbling down". The very importance of the unions after the war proved the WFTU's downfall, for the world of labor became one of the main battlegrounds of the Cold War. The collapse of the Grand Alliance heralded a rapid decline in the importance of the trade unions. The structure of world

14 Quoted in Harrison, Trade Unions and the Labour Party since 1940 (London, 1960), p. 123n. from N. Dennis, F. Henriques, and C. Slaughter, Coal is Our Life (London, 1956), pp. 166-167.

"S Citrine detailed his position to the AFL in 1942. Excerpt from AFL Executive Council Minutes, 20 May 1942, Box 6 File 3, Philip Taft Papers, Labor Management Documentation Center, M. P. Catherwood Library, Cornell University, Ithaca. See also: Weiler, British Labour and the Cold War, pp. 55-61. 
politics which evolved in the late forties and early fifties had little room for an independent world labor movement. The loyalty of the working class to one side or the other on every continent was a crucial issue for the contending governments. Even as it accentuated the importance of working-class political thought, the Cold War in Europe precluded an autonomous role for working-class organizations. Similarly, in the Third World union conflicts flared between Communists and their opponents. In the charged atmosphere of the late forties, working-class politics became too important in the eyes of national policy-making elites to be left to workers. The lack of powerful popular forces in support of the international labor movement in two of the most important non-Communist union centers fatally weakened the WFTU. Without effective support in the unions of the western side in the Cold War, the international labor movement could not resist the division of the world into polarized, armed camps. 